\title{
Introduction to A Research Agenda for Digital Politics
}

\author{
William H. Dutton
}

Many of the big questions concerning contemporary societies are about digital politics. In this book, a number of freshly minted agendas are put forward for research that could shed light on such questions as the following: Will the Internet and related digital media bring democracy to the world, or 'kill' democracy (Bartlett, 2018)? Are digital media reconfiguring access to information and people in ways that will empower citizens? Will the technologies of search and social media enable the public to be better informed about a wider range of issues, or will they be trapped in filter bubbles and echo chambers? Have digital media undermined mediating institutions, such as the quality press, in ways that are fostering nationalist and populist sentiments? Are social media and distributed intelligence leading to the 'death of expertise' (Nichols, 2017)? Will individuals be able to protect their privacy online, or will their personal data be mined by the big tech companies (Zuboff, 2019)? Will the Internet platforms centralize more power in the big tech giants, media and governments, while undermining the promise of a distributed network of individual Internet users, such as by limiting their freedom and choice (Citton, 2019)?

Answers to such questions are too often dominated by deterministic assumptions of utopian and dystopian commentators, although the pendulum of opinion has swayed heavily to the side of dystopian perspectives. Gone are the days of utopian visions of the Internet bringing democracy to the world. Quite the contrary. We are in a clearly dystopian context in which the Internet and related digital media are viewed by many as contributing to, if not causing, serious harm in politics and society (Keen, 2015; Bartlett, 2018). Even research is increasingly framed and critiqued from partisan perspectives, undermining trust in the research enterprise itself. However, you will find that the contrib- 
utors to this book are neither cheerleaders for new technology, nor are they fearmongers. You will see a genuine effort by these scholars to be thought leaders in a field that is increasingly riven with deterministic thinking and partisan suspicions.

Beginning with a few of the most fundamental issues of definition, this introductory chapter identifies some key themes of research into digital politics, along with important issues facing researchers in this field, ranging from the methodological to the ethical. It notes the growing scale and sophistication of research into digital politics as one of the most critical areas of research on the social shaping and implications of technology and society (Dutton and Dubois, 2014). More researchers should be thinking about more aspects of digital politics in ways that challenge conventional wisdom and revisit early research conclusions in light of a fast-paced set of developments already taking place or visible on the horizon.

In short, academic research should be sceptical of conventional wisdom and journalistic debate lines, whether positive or negative, and seek to inform debate over these big public issues by framing questions that can be reliably and validly addressed through high-quality research. This book sets out to frame these questions.

\section{What is digital politics?}

Everything seems to be digital and everything is political, from who controls the remote control to who wins elections. But digital politics is neither an unmanageably large set of topics for research, nor too narrowly defined. Digital politics refers primarily to an increasing tendency for political actors to interact and channel their goals, strategies, activities and messages through digital platforms and media. It also enables networked individuals to respond more often and more rapidly to those actors' messages, as well as to exchange ideas with one another in narrow, wide or multiple circles. The ways and means of doing so are numerous, varied and ever evolving with innovations in digital media, communication and information technologies and their growing range of applications.

One need not be a determinist to realize that such innovations matter. They can reinforce existing structures and relationships, but in some sectors of politics and communication the consequences of this trend can be truly transformational. Hence, there is a need for continually updating agendas of 
research into their use and implications. While you will find each chapter of this volume providing a unique perspective on future research, you will also find some cross-cutting themes.

\section{Themes across multiple agendas for research on digital politics}

The diverse agendas offered by the contributors to this book suggest a set of cross-cutting themes behind their own unique perspectives on digital politics.

\section{The implications of convergence}

Earlier research on the political aspects of information and communication technologies was distinct from media research, and most often focused on specific technologies such as personal computers, interactive cable, videotext and satellites, joined by rising foci around the Internet, social media, mobile Internet, artificial intelligence (AI) and algorithms. Even broad terms often had a limited focus. 'Information technology' (IT) was coined in the 1950s and generally referred to computing and data-processing systems, but as computing increasingly networked people, 'information and communication technologies' (ICTs) became a better covering term. But even this broad conception did not incorporate the analogue, linear, mass media of radio, television and film. Likewise, the concept of 'media' and later 'new media', that addressed interactive cable, videotext, and more, did not necessarily cover more basic ICTs, such as the Internet and social media.

However, as technologies of ICTs and media have been converging, all moving to digital technologies, the concept of 'digital' became a broader and more useful covering term. As you will see in this book, there is still a need to focus on research anchored in non-digital technologies (see Blumler, Chapter 3 in this volume), and most research on Internet politics and digital politics is anchored in a hybrid world of analogue and digital media (Chadwick, 2006). But digital puts together technologies of the Internet and social media with more traditional media as they all move into digital forms and online across multiple devices. For instance, next-generation online television is likely to have many elements in common with the Internet and social media, all being digital media (Noam, 2019). What are the implications of this convergence to digital media? 


\section{Fragmentation amidst concentration}

Technical convergence may reinforce major patterns of national and global concentration within the telecom and big tech and Internet firms: the so-called Big Nine tech giants (Crawford, 2013; Webb, 2019), as the companies build on the economies of scale inherent in digital networks. However, technical convergence and concentration are not erasing other differences across media (telecom, television, films, news, blogs, social media, and so on), ranging from their ideology to their markets, business models and regulatory regimes, which constrain convergence simply on technical grounds (Garnham, 1996). In fact, a complementary theme of a number of contributions concerns the increasing fragmentation of messages and audiences in the new digital environment.

Media researchers have worried about the fragmentation of audiences ever since the number of television channels began to multiply. Elihu Katz (1996) captured this angst in 'deliver us from segmentation'. How could mass media help to integrate the public around common texts and ideas? But segmentation and fragmentation of the public is arguably greater in the digital media context. Networked actors and individuals are producing and consuming content across multiple platforms, different social media, competing streaming services and a myriad of news services. Fragmentation makes it even more difficult to build a common understanding of events or news, for example, or to control disinformation, as different individuals use different sources (Dutton et al., 2019). However, it also makes it more difficult for any single actor to control the public's exposure to political content; for example, when they access multiple and different sources for political information. Is this a transitional period or, despite convergence and growing concentration of the media, will political actors be more fragmented, and for the better or worse?

\section{Following the changing technological infrastructure of digital politics}

Given the pace of technical change, the study of digital politics is more subject to demands to focus on the latest technical innovation than are many other fields. In many cases, it is useful to study new technologies, if only to more critically understand what they actually entail. For example, electronic voting can follow many different designs, such as remote Internet voting or replacing punch cards at voting stations with electronic machines. What is a smart city? Could there be aspects such as surveillance that are hidden by such a catchy label? What is a 'deep fake' and how can it be detected?

Nevertheless, researchers need to ensure that their agendas do not simply chase the most recent technical innovations, but pursue more fundamental 
questions about the political shaping and implications of digital media. In that spirit, it is possible that no technological change has been more significant than the continued worldwide diffusion of the Internet and digital media more generally, what Nanna Bonde Thylstrup (2018) calls 'mass digitization'. Since the Internet reached over half the world's population in 2019, and nearly everyone in high-income nations, the political implications of digital media have become inescapable and increasingly significant around the world. This shift in the technological infrastructure of digital politics has helped to bring more researchers into the study of digital politics, as they realize that digital politics is the new reality, but also still in its early stages of development and use in politics and society.

\section{Challenging assumptions of the political bias of digital technologies}

From the telegraph to AI, technical changes such as the move to digital are interesting as, to paraphrase Harold Lasswell (1971), they might have implications for who gets what, when, where and how. Ithiel de Sola Pool's (1983) conception of 'technologies of freedom' captured his argument that there was a 'soft technological determinism' behind the role of digital media, as they were inherently biased toward more democratic forms of access. This assumption was still prevalent in the late 1990s, when a focus was on 'digital democracy' (Dutton, 1999: 173-93). Of course, research sought to question this conventional wisdom, but this was the dominant hypothesis about the role of the new media. However, in the early decades of the twenty-first century, multiple uses of the Internet in support of autocratic regimes undermined this perspective (Howard, 2011). Yet, as I write, social movements around the world are being orchestrated through various social media in ways that seem to resurrect an earlier vision of the network of networks as a technology of freedom.

Given such uncertainties, 'digital politics' is a useful covering term because it does not embed specific assumptions about whether digital media are biased toward more democratic (decentralized) or autocratic (more hierarchical) models of political control; it is open to findings in many alternative directions. The outcome is not prejudged, even if the aim of many researchers might well be focused on strengthening democratic institutions and processes, such as by enhancing the engagement of citizens in the political process, as this entails research on counter-arguments, such that digital media might lead to 'clicktivism' that distances citizens from real politics. Over time, the thrust of empirical research has been to support the tendency of technology to be sufficiently malleable that it can be designed and used in ways that reinforce existing structures and influence; what my colleagues and I called 'reinforcement politics' 
(Danziger et al., 1982). Nevertheless, the potential and actual nature of power shifts remains a persistent element of the research agenda of digital politics.

\section{Considering the potential for new organizational and institutional forms}

The expectation of power shifts is built in part on the idea of organizational change, such as what Harlan Cleveland (1985) described as the 'twilight of hierarchy'. As you will see in several contributions to this book, there is a new transformative thesis emerging, albeit not focused on democratization or autocracy. Various authors see digital politics leading to new organizational forms, such as new types of political parties (Gerbaudo, this volume), and new threats to democratic citizenship, such as around the erosion of privacy (Zuboff, 2019; Lievrouw, Chapter 16 in this volume). As noted above, digital media might enable individuals, corporations and governments to use digital media to reconfigure access to information, people and services in often unpredictable ways, placing a major premium on empirical research into the actual implications of technological change.

These new forms are associated in some treatments with the rise of digital platforms. For example, in the early years of the Internet, electronic democracy initiatives were focused on governmental and civil society innovations, such as Santa Monica, California's first electronic city hall, the Public Electronic Network (PEN). Over time, these initiatives have been more focused on platforms, for example social media platforms, such as Facebook or Twitter, and their use by individuals, political parties and advocacy groups (Karpf, 2012; Tufekci, 2017; Gerbaudo, Chapter 4 in this volume).

\section{Challenging technologically deterministic assumptions}

The importance of empirical research on the actual use and impact of digital media is also reinforced by a resurgence of technologically deterministic expectations, such as around the idea of filter bubbles (Pariser, 2011). From such perspectives, algorithms and artificial intelligence will determine what we know and whom we know. But many contributions to this book have a strong empirical and more inductivist approach, looking at qualitative and quantitative research for the actual implications of technical change in particular contexts. As noted above, the fragmentation of digital politics makes it less likely for an individual to be trapped in a filter bubble (Dutton et al., 2019). Nevertheless, deterministic perspectives such as echo chambers and filter bubbles are intuitively appealing and can provide easy answers to burning questions, such as around the greater polarization of politics, and catch on 
among pundits and academics alike. But deterministic perspectives need to be challenged.

\section{The emergence of new questions and old questions in new forms}

Many questions about the political implications of media, communication and information technologies are not new, such as around questions of power shifts. But in the early years of research on the political aspects of ICTs, much was based on speculation about what could be done. For example, early work on 'teledemocracy' was focused on whether interactive cable, videotext or electronic bulletin boards might be designed to support voting or polling. Was electronic voting feasible, and how would it be done? Would the Internet provide new channels for politicians to communicate with citizens? Will electronic forums and social media enable a public sphere? Will political, economic or institutional brakes constrain the development of digital government services? Will digital divides create inequities in access?

So many contemporary issues are cases of old wine in new technological bottles. For example, rising concerns over vote tampering and the security of electronic voting systems follows early warnings about the difficulties of security and authentication of actual votes. The idea of filter bubbles is focused on whether the rules and assumptions built into search algorithms might bias the outcomes of the algorithms behind search, such as limiting a user's access to more diverse sources of information. Older research on models in policy-making looked at very similar issues, such as determining the underlying assumptions and rules governing models of the impact of urban development (Dutton and Kraemer, 1985). Were they biased in ways that supported one type of development over another, such as urban infill versus urban sprawl?

Over time, however, the capability of technologies to support tasks that might have seemed like 'blue sky' thinking in earlier years has been demonstrated, such as electronic voting, or the use of $\mathrm{AI}$ in search, or face recognition in identification. This will not silence debate about the adequacy of the design of these technologies, but given these advances, debate has shifted more discussion to ethical issues of what should be done. You will see this in a number of contributions to this volume, such as in the discussion of rethinking citizenship in the digital age. This is a relatively new development that is certain to become more prominent in future research. 


\section{New methods and new data}

Of equal importance in a number of chapters of the book are ideas about how we answer the important questions: what are the major methodological issues that are facing the field, such as around access to appropriate and reliable data on what needs to be measured versus what is easily measured? Too often in digital and computational research, the questions often seem to follow the availability of data. Instead, research questions should be guiding the design, collection and analysis of data. But even if one wished to follow the data, access to data is becoming more challenging, such as in response to concerns over privacy and data protection.

You will see in this volume a number of concerns raised about access to data for research, but also about ethical access to data. Just as tech companies have been taken to task for violating the privacy of their users, so have researchers been held accountable for the inappropriate use and sharing of personal data, fostering new academic regimes for approving research involving personal data.

\section{The maturing of an emerging field}

Finally, as a researcher in this emerging field since the mid-1970s, the contributions to this volume demonstrate a growing sophistication, and a heightened stage of maturity of this field. There is less focus on technologies, for example, and more focus on theory. You will see a wide range of theoretical perspectives from different disciplines being drawn from by the contributors to this volume. Moreover, there is less of a separation between legacy media, new media studies and digital politics. There is less deterministic thinking. The disciplinary diversity and methodological sophistication of the field is impressive. The field has moved from a handful of interdisciplinary researchers focused on technical innovations, to an increasingly large range of scholars from multiple disciplines and a diversity of theoretical perspectives who share a commitment to the study of digital politics. 


\section{The outline of this book}

The book is structured in five interrelated parts. Part I introduces the field of digital politics and key issues in its future. Entitled 'Transformations and Continuities', this introductory part begins with two chapters that make a strong case for how the significance and study of digital technologies and politics has been transformed over the last decade, while the third chapter implores us not to dismiss the contributions of past decades.

Andrew Chadwick (Chapter 1) warns us that we are facing nothing less than a 'new crisis of public communication'. Dramatic events have drawn digital media from the periphery of politics into the centre of controversies over the very future of politics and democracy. According to Chadwick, this has posed a number of unprecedented challenges to scholars in this area, but also provided new opportunities for research which he outlines on the social and psychological dynamics shaping the role of social media in opinion formation. The case for new opportunities is built on by Nick Anstead (Chapter 2), who delivers an inspiring case for research priorities in this field, identifying three key challenges, including the tension between the study of the traditional and the new media environments. He described one risk tied to the excitement surrounding digital politics: scholars entering this field can unwisely neglect a rich history of research on the media and politics that has not been made redundant by new technologies. This theme is joined by Jay Blumler's (Chapter 3) contribution, which identifies key questions, concepts and theories anchored in 'legacy research'. He shows how major aspects of legacy research remain central to digital politics.

In Part II, the chapters move to one of the most central concerns around new technology and politics: the conduct of campaigns and elections. Most of the literature on politics and new media have focused on this area (Dutton and Dubois, 2014), although past work has tended to underscore a relatively limited role and impact of new technology, far from the breathtaking expectations during the early diffusion of the Internet and Web. In stark contrast, Paolo Gerbaudo (Chapter 4) begins this section with a dramatic illustration of the transformative political implications of digital platforms shaping the nature and role of political parties. His thesis and examples provide vivid illustrations of the transformative role of digital media. Declan McDowell-Naylor (Chapter 5) continues this transformational theme, focusing on the many uses of digital campaigning by political parties, along with the challenges they raise for candidates and parties in reaching voters. He identifies key substantive and 
methodological issues confronting research in this area, creating a range of topics for future research on election campaigns.

Laleah Fernandez (Chapter 6) also addresses the issues raised by digital media in campaigns, but also draws from her own background in advertising and communication to suggest major areas for research. These include concerns over malicious actors and their use of bots and misinformation, and the ethical issues confronting digital advertising in politics. Wan-Ying Lin and Xinzhi Zhang (Chapter 7) shift discussion from the liberal democratic contexts of North America and Europe to the People's Republic of China, where the use of digital media is more constrained by governmental restrictions on protests and other actions that challenge governmental elites. The chapter illuminates the cut and thrust of digital politics in a more restrictive context, where censorship or other sanctions can push politics into less explicitly political contexts, such as when political views gain expression through humour and everyday use of social media. This chapter is suggestive of patterns of expression that might be less visible but no less significant in other political contexts.

Part III continues the theme of transformation but shifts the focus to institutions beyond those of campaigns and elections. Volker Schneider (Chapter 8) begins this section with a theoretically and empirically rich focus on digital-era governance and its implications for the power of the state and the very nature of policy-making. He asks whether state power will recede or have a renaissance in seeking to control and regulate digitization, and what new actors will assert themselves in the policy-making process. Giles Moss and Heather Ford (Chapter 9) follow on well from the previous chapter in addressing the rise of a new institutional form - the digital platform, such as created by the big tech companies - that would not have been treated in early research on politics and the Internet. As platforms become more powerful in shaping access to information and people, should they be more accountable? How can this accountability best be exercised? Finally, Part III ends with a contribution by M.I. Franklin (Chapter 10) on the future of human rights in a digital age, threatened by the loss of privacy and the rise of digital surveillance. In light of these challenges, she proposes a refreshingly 'radical research agenda', which she sees as central to emerging technologies that are 'environmentally sustainable'.

From institutions, Part IV moves to different modes of communication, including informational, symbolic and communicative actions. In the early years of social media, debate often focused on the relative value of 'clicktivism' versus real political participation, such as street protests. Dave Karpf (Chapter 11) tells us that we should move on to other issues around advocacy and activism that move beyond debate over clicktivism, as the distinctions between 
online and offline behaviour become increasingly blurred. In support, he offers four new directions for research on activism and advocacy.

Of course, many profound political issues are not only over the (re)distribution of material resources, but over symbolic issues, whether they involve demonstrations of patriotism, the use of politically charged words and phrases, or other symbolic acts. Lone Sorensen (Chapter 12) focuses on some key actors and events that have used the digital media to take symbolic politics into new forms, such as in providing the very basis for a major political campaign. In doing so, she makes the case for a performance perspective on how meanings are shaped in the digital sphere, noting the constraints on bringing such a perspective into the digital politics field. Finally, Ben O'Loughlin and Alexi Drew (Chapter 13) argue that nothing speaks louder than actions to demonstrate a commitment to cyber-security. In some respects, actions on cyber-security can become a form of symbolic politics as actors seek to frame the Internet as a 'space of war on elite and public opinion'. This chapter illustrates how digital politics can meaningfully inform the study of cyber-security and other subject areas, such as public health, that might seem remote from this politics as traditionally framed.

The final part of this book (Part V) focuses on ways in which digital politics might be reshaping democratic processes: not only forms of discourse, but also the very idea of citizenship. In the aftermath of the 2016 United States presidential election, and Brexit in the United Kingdom, concerns over the civility of political discourse have risen, with many attributing this to the Internet and rising use of social media. Patrícia Rossini (Chapter 14) focuses on the incivility of political discourse, seeking insights on how to reduce the 'toxicity' of the online public sphere, without excluding the voice of those who cross some lines of civility. Scott Wright picks up aspects of this theme but focuses on what is called a 'third space' - rather than a public sphere - and asks whether this space could be Facebook. While Facebook has become a focus of criticism, particularly in the wake of the Cambridge Analytica scandal, this platform has over 2.4 billion active users, and continues to diffuse worldwide. Might Facebook become central to building a global online community, as envisioned for nearly half a century by pioneers of the Internet?

The next two chapters focus on the changing nature of citizenship - core to democratic political systems - in the digital age. Leah Lievrouw (Chapter 16) wonders if the very essence of citizenship is under threat from the degree that major Internet platforms mine the data of individuals in ways that could undermine rather than enhance the ability of individuals to access information of their choosing, and express their views in ways that are accessible to others. 
Are citizens becoming 'data subjects', controlled by what platforms can collect and mine about individuals and groups? This theme is complemented and broadened by Elizabeth Dubois and Florian Martin-Bariteau (Chapter 17), who assert that no one in advanced economies can 'opt out' of the digital realm. And, therefore, not only does the very act of being a citizen need to be reconceptualized, but also leaders need to rethink traditional policies and practices for this digital age. The authors point to research that could advance this agenda.

In the last chapter of Part V, and this book, Stephen Coleman (Chapter 18) provides a powerful call for the research community to step up to the challenges of moving the study of politics into the realities of the twenty-first century. In a digital public sphere epitomized by often toxic, angry discourse, outrage, and polarization, what can be done? Coleman senses that digital politics has indeed broken traditional forms of politics, requiring us to 're-imagine' democratic processes and the democratic public in ways that individuals can feel efficacious and be heard through what is nothing less than a 'new discourse architecture', his agenda for digital politics research.

\section{Conclusion}

These 18 chapters cover much ground, but many important topics for digital politics remain beyond the scope of one book. The politics of regulating the Internet and social media, and the household politics of digital media use, such as screen time, are not in focus, even if they are undoubtedly important. Nevertheless, these chapters aim to stimulate the debates and insights that will set an agenda for research on digital politics, influencing what researchers think about in the coming years (McCombs and Shaw, 1972).

This book presents the thinking of some of the leading experts in this rapidly evolving and maturing field. It is neither comprehensive nor omniscient. You and others will shape this agenda, as you follow and participate in one of the most dynamic and controversial fields of social and political research of this century. Fifty years after the birth of the Internet, the impact of digital media is only beginning to be fully appreciated and studied as a critical means for political actors, including a public of networked individuals - digital citizens to interact and channel their goals, strategies, activities and messages in ways that will shape the vitality of democracy, citizenship and political participation in the digital age. 


\section{References}

Bartlett, J. (2018) The People Vs Tech. London: Ebury Publishing.

Chadwick, A. (2006) Internet Politics. New York: Oxford University Press.

Citton, Y. (2019) Mediarchy. Cambridge: Polity Press.

Cleveland, H. (1985) 'Twilight of Hierarchy', Public Administration Review, Jan.-Feb., pp. 185-95.

Crawford, S. (2013) Captive Audience. New Haven, CT: Yale University Press.

Danziger, J.N., Dutton, W.H., Kling, R. and Kraemer, K.L. (1982) Computers and Politics. New York: Columbia University Press.

De Sola Pool, I. (1983) Technologies of Freedom. Cambridge, MA: Belkap.

Dutton, W.H. (1999) Society on the Line: Information Politics in the Digital Age. Oxford: Oxford University Press.

Dutton, W.H. and Dubois, E. (2014) Politics and the Internet, Vols I-IV. London, UK and New York, USA: Routledge.

Dutton, W.H. and Kraemer, K.L. (1985) Modeling as Negotiating: The Political Dynamics of Computer Models in the Policy Process. Norwood, NJ: Ablex.

Dutton, W.H. and Peltu, M. (eds) (1996) Information and Communication Technologies: Visions and Realities. Oxford: Oxford University Press.

Dutton, W.H., Reisforf, B.C., Blank, G., Dubois, E. and Fernandez, L. (2019) 'The Internet and Access to Information about Politics'. In M. Graham and W.H. Dutton (eds), Society and the Internet, 2nd edition. Oxford: Oxford University Press, pp. 228-47.

Garnham, N. (1996) 'Constraints on Multimedia Convergence'. In W.H. Dutton and M. Peltu (eds) Information and Communication Technologies: Visions and Realities. Oxford: Oxford University Press, pp. 103-19.

Howard, P.N. (2011) The Digital Origins of Dictatorship and Democracy. New York: Oxford University Press.

Karpf, D. (2012) The MoveOn Effect: The Unexpected Transformation of American Political Advocacy. New York: Oxford University Press.

Katz, E. (1996) 'Deliver Us from Segmentation', Annals of the American Academy of Political and Social Science, 546 (July), pp. 22-33.

Keen, A. (2015) The Internet Is Not The Answer. London: Atlantic Books.

Lasswell, H.D. (1971) 'The Structure and Function of Communication in Society'. In W. Schramm and D.F. Roberts (eds), The Process and Effects of Mass Communication, rev. edn. Chicago, IL: University of Chicago Press, pp. 84-99.

McCombs, M.E. and Shaw, D.L. (1972) 'The Agenda-Setting Function of Mass Media', Public Opinion Quarterly, 36(2), pp. 176-87.

Nichols, T. (2017) The Death of Expertise. Oxford: Oxford University Press.

Noam, E. (2019) 'Looking Ahead at Internet Video and its Societal Impacts'. In M. Graham and W.H. Dutton (eds), Society and the Internet, 2nd edition. Oxford: Oxford University Press, pp. 371-88.

Pariser, R. (2011) The Filter Bubble. New York: Penguin Books.

Thylstrup, N.B. (2018) The Politics of Mass Digitization. Cambridge, MA: MIT Press.

Tufekci, Z. (2017) Twitter and Tear Gas. New Haven, CT: Yale University Press.

Webb, A. (2019) The Big Nine. New York: Hachette Book Group.

Zuboff, S. (2019) The Age of Surveillance Capitalism. London: Profile Books. 
William H. Dutton - 9781789903096 Downloaded from PubFactory at 04/26/2023 12:18:05PM via free access 